\title{
Pendampingan dan Pengembangan Manajemen Pemasaran Produk UMKM Melalui Teknologi Digital Di Masa Pandemi Covid-19
}

\author{
Syaeful Bakhri ${ }^{\mathrm{a}, 1}$, Vuvut Futiah ${ }^{\mathrm{b}, 2}$ \\ ${ }^{a}$ Fakultas Syariah dan Ekonomi Islam, IAIN Syekh Nurjati, Cirebon* \\ ${ }^{\text {b} F a k u l t a s ~ I l m u ~ T a r b i y a h ~ d a n ~ K e g u r u a n, ~ I A I N ~ S y e k h ~ N u r j a t i, ~ C i r e b o n ~}$ \\ ${ }^{1}$ sultan01aulia@yahoo.com; ${ }^{2}$ futiahvuvut11@gmail.com \\ *korespondensi penulis
}

Naskah diterima: 20 Juli 2020, direvisi: 1 Agustus 2020, disetujui: 4 September 2020

\begin{abstract}
Abstrak
Tujuan kegiatan pendampingan ini adalah sebagai respon atas temuan kebiasaan baru pelaku UMKM di era digital sekaligus di era pandemi Covid-19 yang berdampak pada diberlakukannya peraturan pembatasan sosial, sehingga perlu diupayakan penciptaan kebiasaan bisnis baru yang unggul dan kompetitif salah satunya adalah terkait manajemen pemasaran produk yang dilakukan melalui teknologi digital. Metode yang dilakukan dalam kegiatan ini adalah menggunakan metode Participation Action Research (PAR) yang mana dalam pelaksanaanya dilakukan melalui metode pendekatan secara partisipatif, kemudian diimplementasikan ke dalam sebuah aksi. Kegiatan pengabdian dilakukan dengan cara pendampingan produksi limbah ban karet pada kelompok pengrajin UMKM serta pembuatan sarana marketing melalui digital marketing berbasis sosial media. Dengan adanya kegiatan pengabdian ini, kelompok UMKM memiliki label produk dan sekaligus memiliki sarana marketing yang bervariasi berbasis media sosial seperti Instagram, Youtube, dan Facebook yang dilakukan melalui teknologi digital. Strategi ini secara langsung mampu meningkatkan dan mengembangkan nilai jual pengrajin UMKM limbah ban bekas, sehingga distribusi produk dalam pasar domestik dapat terselamatkan di masa pandemi Covid-19.

Kata-kata kunci: Limbah Ban ; UMKM ; Teknologi Digital; Covid-19
\end{abstract}

\section{Abstract}

The purpose of this assistance activity is in response to the findings of new habits of MSME players in the digital era and the era of the Covid-19 pandemic, which has an impact on the enactment of social restriction regulations. So it is necessary to create new business habits that are superior and competitive, one of which is related to product marketing management-done through digital technology. The method used in this activity is to use the Participation Action Research (PAR) method, which in practice is carried out through a participatory approach method, then implemented into action. Community service activities are carried out by assisting rubber tire waste production to groups of MSME craftsmen and making marketing facilities through social media-based digital marketing. With this service activity, the MSME group has a product label and, at the same time, has various marketing tools based on social media such as Instagram, Youtube, and Facebook, which are carried out through digital technology. This strategy can directly increase and develop the selling value of used tire MSME artisans, so that product distribution in the domestic market can be saved during the Covid-19 pandemic.

Keywords: Waste Tire; MSME; Digital Technology; Covid-19 


\section{PENDAHULUAN}

Di era serba modern ini semua hal dapat dikembangkan secara canggih melalui penggunaan teknologi digital. Indonesia merupakan negara berkembang yang memiliki berbagai jenis keanekaragaman baik dalam hal agama, suku, adat dan budaya yang tersebar di seluruh wilayah kesatuan Republik Indonesia. Di bidang perekonomian dan tata usaha, semua jenis usaha yang beraneka ragam, dan kreativitas masyarakat Indonesia sudah sepatutnya kita satukan semua komponen tersebut menjadi suatu kesatuan untuk dapat bersaing menghadapi revolusi industri 4.0 yang kian dinamis dan dramatis.

Seperti yang sudah kita ketahui bersama bahwa UMKM adalah salah satu sektor yang memiliki peranan yang cukup besar terhadap perekonomian nasional. Berbagai literatur terdahulu mencatat terkait eksistensinya yang tetap mampu bertahan bahkan di saat kondisi krisis ekonomi sekalipun (Nugrahani, 2015). Dalam (Amri, 2020) dijelaskan pula bahwa UMKM di Indonesia kini sudah mulai mengenal dan memanfaatkan kemajuan teknologi perihal daya komputerisasi, kecerdasan buatan untuk bergeser pada material yang lebih ramah lingkungan dari semua jenis. Demi terciptanya sumberdaya yang murah, melimpah dan bersifat sustainable, pelaku
UMKM dituntut untuk mempersiapkan diri dengan menciptakan hal baru baik itu melalui pemanfaatan teknologi maupun energi yang baru.

Pandemi Covid-19 merupakan pandemi yang terjadi secara global yang sudah mengguncang stabilitas ekonomi pada berbagai negara termasuk Indonesia. Berdasarkan data Kementerian Koperasi dan UMKM diketahui bahwa sektor UMKM ikut terguncang selama adanya pandemi Covid19. Hal ini dikarenakan UMKM menempati posisi strategis dalam perekonomian secara umum sehingga banyak yang menutup usaha sementara waktu dan bahkan banyak juga yang mengalami kendala pada arus kas (Sugiri, 2020). Seiring dengan kondisi tersebut pemerintah sedang berupaya untuk menjadikan sistem kebijakan ekonomi industri dan kreatif demi mengimbangi guncangan yang terjadi pada sistem permodalan, produksi dan sistem penjualan sebagai akibat dari terhambatnya aktivitas distribusi pada wilayah-wilayah tertentu (Amri, 2020).

Temuan kebiasaan baru pelaku UMKM di era digital sekaligus di era pandemi Covid19 yang berdampak pada diberlakukannya peraturan pembatasan sosial, perlu terus diupayakan menuju penciptaan kebiasaan bisnis baru yang unggul dan kompetitif. Hal 
ini disebabkan karena ekosistem industri kini sudah banyak yang berubah dan secara langsung menuntut para pelaku UMKM untuk ikut menyesuaikan diri seiring dengan pesaing yang juga ikut berubah. UMKM di masa pandemi Covid-19 dapat berinovasi melalui pemanfaatan teknologi digital tidak terkecuali dalam hal pemasaran produk UMKM. Sebagaimana menurut (Hardilawati, 2020) yang menyatakan bahwa pemasaran melalui pemanfaatan teknologi digital atau yang biasa disebut sebagai digital marketing dapat membantu pelaku usaha dalam hal mempromosikan dan memasarkan produk dan jasa mereka tanpa adanya batasan jarak, waktu dan cara komunikasi. Hal yang juga telah dibuktikan berdasarkan hasil penelitian (Hendrawan, 2019) yang mengindikasikan kebenaran digital marketing yang dapat mempengaruhi secara positif dan signifikan terhadap peningkatan kondisi pemasaran produk UMKM.

Strategi pemasaran menurut (Nugrahani, 2015) dianggap sebagai komponen esensial yang mampu mengendalikan keberhasilan penerimaan produk kepada masyarakat luas, namun hal tersebut masih banyak yang menganggap sepele. Minimnya perhatian para pelaku UMKM terkait dengan strategi pemasaran dapat mengakibatkan banyaknya bisnis UMKM tersendat, terlebih di masa sulit seperti pandemi Covid-19 ini. Meskipun kualitas produk yang dihasilkan baik, namun jika suatu produk tidak mampu dipasarkan secara baik maka tidak akan menghasilkan sebuah nilai jual pada produk tersebut.

Kabupaten Cirebon adalah salah satu Kabupaten di Provinsi Jawa Barat yang memiliki banyak beragam industri UMKM salah satunya adalah pengrajin UMKM yang memanfaatkan limbah ban bekas yang terletak di Desa Kasugengan Lor. Masyarakat di Kasugengan Lor beranggapan bahwa limbah ban adalah barang bekas yang memiliki nilai ekonomis dan mampu meningkatkan kehidupan ekonomi bagi sebagian besar masyarakatnya Hal ini yang menjadi alasan sebagian besar masyarakat di Desa Kasugengan Lor adalah bermata pencaharian pelaku UMKM pemanfaatan limbah ban bekas. Dari karet ban bekas tersebut sebagian besar dijadikan sebagai kursi karet, pot karet, tempat sampah karet, dan lainnya.

UMKM di Kasugengan Lor yang banyak memanfaatkan ban karet bekas merupakan salah satu UMKM Kabupaten Cirebon yang memiliki banyak potensi usaha yang mampu bersaing pada pasar domestik maupun mancanegara. Namun sejak adanya pandemi Covid-19, pemasaran produk mengalami penurunan karena tersendatnya proses distribusi pengiriman produk yang 
tidak dilakukan berjalan normal. Dalam hal ini perlu disusun strategi manajemen pemasaran yang dapat memulihkan kondisi penjualan produk para pengrajin UMKM limbah ban bekas demi mempertahankan eksistensinya di dunia industri.

Berdasarkan pemaparan fenomena tersebut, penulis merasa perlu untuk melakukan pendampingan kepada para pengrajin limbah ban bekas di Kasugengan Lor sebagai langkah mendukung pengembangan usaha kursi karet agar lebih maju dan tidak menutup kemungkinan juga dapat mempengaruhi kehidupan ekonomi para pengrajin UMKM limbah ban di Kasugengan Lor.

\section{METODE}

Metode yang dilakukan dalam kegiatan ini adalah dengan cara melakukan pendampingan. Pendampingan merupakan sebuah alat yang sering dipergunakan dalam kegiatan pemberdayaan masyarakat sebagai upaya membantu mengembangkan dan mewujudkan tujuan individu maupun kelompok masyarakat.

Pendampingan dan pemberdayaan (empowering) merupakan bagian dari metode Participation Action Research (PAR). Sebagai sebuah metode pengabdian, PAR menurut (Soedarwo, Zuriah, Yuliati, \& Suwignyo, 2017) memiliki karakteristik dalam kegiatannya yaitu merencanakan sebuah perubahan; mempelajari dan mengamati proses dan konsekuensi perubahan; mengkaji proses dan konsekuensi tersebut; mengkaji proses dan konsekuensi tersebut; merencanakan ulang; mempelajari dan mengamati; mengkaji dan demikian seterusnya. Terdapat beberapa elemen penting yang perlu diperhatikan dalam kegiatan pengabdian dengan metode PAR. Yaitu menurut (Mahmudah, Chasanatin, Alkautsar, \& Paripurna, 2020) antara lain:

1. Memunculkan kesadaran dalam masyarakat, memahami, menyadari bahwa ada sistem nilai dalam masyarakat.

2. Setelah mengetahui informasi sekaligus memahami permasalahan bersama masyarakat melalui diskusi kelompok kecil dan mencari solusi bersama dengan dilakukannya dengan hati-hati sebab permasalahan sesungguhnya berasal dari konflik yang menyangkut kepentingan masyarakat

3. Metode PAR terdiri dari tiga kata yang saling berhubungan yang saling keterkaitan, yaitu Partisipasi, riset dan aksi. Artinya hasil riset yang telah dilakukan secara partisipatif kemudian diimplementasikan ke dalam sebuah aksi. Aksi yang didasarkan kepada riset partisipatif yang benar akan menjadi tepat sasaran. 
Dalam pengumpulan data, kegiatan dilakukan melalui metode observasi dan wawancara. Wawancara yaitu keadaan berhadap-hadapan antara pewawancara dan narasumber dengan tujuan mencari informasi dari narasumber yang dituju. Sedangkan observasi yaitu mendatangi secara langsung objek yang akan menjadi bahan penelitian. Selanjutnya tahap analisis data, pada tahap ini peneliti menganalisis data hasil wawancara dan observasi. Mencari referensi dari sumber data yang akurat agar data tersebut absah. Kemudian tahap penyajian analisis data, pada tahapan ini data disajikan dalam bentuk deskriptif. Mendeskripsikan proses pembuatan kursi karet dan strategi pemasaran kursi karet dari ban bekas.

\section{HASIL DAN PEMBAHASAN}

Tahap awal dalam kegiatan pendampingan dilakukan dengan cara pendahuluan, yaitu melakukan proses partisipatif yang dimulai dengan metode pendekatan untuk membangun keterbukaan, dukungan dan keterlibatan masyarakat. Kedekatan yang terjalin antara tim pengabdian dengan kelompok masyarakat akan sangat mendukung proses pengabdian sekaligus hasil pengabdian yang disusun dalam hal perencanaan, pelaksanaan, pendampingan serta monitoring program pemberdayaan masyarakat. Pendekatan dilakukan dengan cara melakukan dialog secara terbuka melalui observasi dan wawancara terkait kondisi usaha kelompok pengrajin limbah ban bekas secara umum, terkait proses pembuatan produk hingga terkait permasalahan-permasalahan dalam pengembangan usaha di masa pandemi Covid-19.

Dalam hal ini, dapat diketahui cara pembuatan kursi karet dari ban bekas membutuhkan proses yang cukup panjang. Karena melalui tahapan-tahapan yang rumit, dimulai dengan ban yang sudah tidak terpakai diolah dan dibentuk menjadi kursi yang nyaman untuk diduduki. Adapun alat dan bahan yang digunakan untuk membuat kursi karet dari ban bekas yaitu sebagai berikut:

1. Alat

Ada beberapa alat yang digunakan untuk proses pembuatan kursi karet yaitu:
a. Mesin potong
b. Diesel
c. Paku
d. Palu
e. Alat penyerut
f. Pisau
g. Gunting

2. Bahan

Ada beberapa bahan yang digunakan untuk proses pembuatan kursi karet yaitu:
a. Ban bekas
b. Kain kursi 
c. Kain sisa

d. Busa

e. Gerinda

f. Cat

g. Bensin

Proses pembuatan produk, diawali dengan cara menyerut limbah ban menggunakan alat penyerut yang terbuat dari kayu dan pisau yang tajam. Penyerutan dilakukan dengan hati-hati dan penuh dengan ketelitian. Hasil serutan karet ini bentuknya memanjang dengan ketebalan $3 \mathrm{~cm}$ dan nantinya akan dijadikan untuk dudukan dan sandaran. Kedua, setelah ban bekas diserut, sisa dari serutan akan menghasilkan yang namanya hil. Hil tersebut dipotong menggunakan mesin potong dan gerinda. Hil dipotong membentuk setengah lingkaran dan akan dijadikan untuk kaki kursi.

Ketiga, proses pemotongan kain kursi dan busa. Kain kursi memiliki banyak motif, motif yang sangat diminati pelanggan yaitu motif bunga. Selain itu kain kursi juga memiliki varian warna, ada warna biru, hijau, ungu, dan merah. Kain untuk bagian dudukan dipotong sepanjang $40 \mathrm{~cm}$ dan kain untuk bagian sandaran dipotong sepanjang $40 \mathrm{~cm}$. Dari potongan dudukan dan sandaran dipotong lagi untuk bantalan tangan sekitar $5 \mathrm{~cm}$. Begitupun dengan proses pemotongan busa, tekniknya sama seperti pemotongan kain.
Keempat, proses penyatuan kaki kursi, dudukan, dan tangan kursi. Ketiga bahan tersebut disatukan dengan cara dipaku dengan kuat agar tidak mudah terlepas. Kaki kursi, dudukan, sandaran, dan tangan kursi berbahan dari hil.

Kelima, pembuatan dudukan dan sandaran kursi. Dudukan dan sandaran kursi terbuat dari hil, lalu hasil serutan dianyam pada tiap tepi hil. Proses anyaman dilakukan dengan posisi rapat seperti menganyam ketupat. Setelah anyaman selesai, pada bagian bawah dudukan diberi busa kemudian diberi kain sisa agar saat duduk nyaman dan aman. Setelah itu di atas kain sisa diberi busa kembali lalu ditutup dengan kain kursi bermotif, selanjutnya dudukan dipaku secara mengeliling dan dilapisi dengan karet ban bekas sepeda. Adapun cara membuat sandaran kursi hampir sama dengan dudukan, yang membedakan adalah sandaran kursi tidak diberi kain sisa, dan bentuk sandaran kursi berbentuk lonjong.

Keenam, proses penyatuan antara dudukan dan sandaran kursi. Dudukan dan sandaran disatukan dengan cara dipaku menggunakan paku berukuran $8 \mathrm{~cm}$. Pada bagian tepi sandaran juga dilapisi menggunakan karet sepeda. Ketujuh, pembuatan bantalan tangan, bantalan tangan dilapisi menggunakan busa dan ditutup dengan kain kursi bermotif lalu dipaku. 
Kedelapan, proses pengecatan pada kursi karet. Menggunakan cat berwarna hitam yang terbuat dari aspal dan dicampur dengan bensin, semua bagian kursi dicat dengan rata tujuannya agar kursi terlihat lebih menarik dan bagus. Semua tahapan tidak dilakukan oleh satu orang, tetapi satu orang hanya membidangi di keahliannya masing-masing.

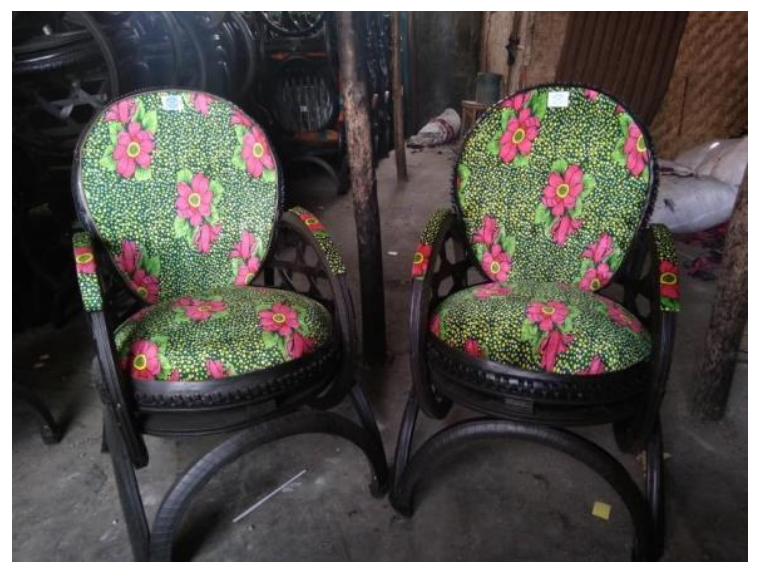

Sumber: Dokumentasi penulis, 2020

Gambar 1. Contoh Produk Kursi Karet

Usaha pemanfaatan limbah karet pada kelompok pengrajin UMKM ini sudah berjalan sejak tahun 2011 silam. Sejauh ini usahanya berjalan dengan lancar, namun sejak adanya pandemi covid-19 adanya penurunan dari jumlah karyawan, peminat atau pembeli, dan lainnya. Faktor yang menjadi penghambat saat pandemi covid-19 ini yaitu faktor ekonomi, menurut pak Ganden saat diwawancara faktor ekonomi menjadi hal yang sangat penting. Karena sejak adanya pandemi di Indonesia semua pekerja dirumahkan dan di PHK. Begitupun karyawan yang bekerja di usaha kursi karet, pemilik usaha kursi karet ini lebih memilih untuk memenuhi kebutuhan keluarganya daripada untuk membelanjakan bahan-bahan untuk pembuatan kursi karet. Selain itu semenjak diberlakukannya PSBB di seluruh wilayah di Indonesia menghambat pula proses jalannya usaha kursi karet. Karena usaha kursi karet milik pak Ganden sudah terkenal hingga ke luar pulau Jawa. Pengirimannya ke Jawa Tengah, Purwokerto, Bobot Sari, Sumatera, Padang, Lampung, bahkan sampai ke Aceh.

Biasanya untuk sekali pengiriman, menggunakan mobil truk. Satu mobil truk muat 30 setel kursi, untuk satu setel berisi 4 kursi dan 1 meja. Strategi pemasaran yang dilakukan yaitu pak Ganden sebagai distributor kursi karet menyalurkan kepada reseller yang ingin mengambil barang. Dari reseller ini akan dipasarkan kepada konsumen. Pengiriman kursi akan dilakukan jika reseller meminta barang, jika tidak maka distributor tidak mengirim barang. Ada pula reseller yang mendatangi langsung ke distributor untuk mengambil barang lalu dipasarkan dengan cara keliling menggunakan mobil pick up. Untuk reseller yang mengambil barang secara langsung ke distributor, jika barang sisa beberapa setel makan akan dikembalikan ke distributor. 
Omzet dari hasil penjualan kursi karet lumayan besar, akan tetapi modal yang dikeluarkan untuk membeli bahan-bahan juga lumayan besar. Perbandingan antara modal beli dengan penghasilan yaitu 1 banding 2 . Ongkos kirim untuk pengiriman juga cukup besar apalagi luar kota. Kursi karet milik pak Ganden diberi nama "Sapta Gumelar" karier usaha kursi karet pak Ganden sudah melejit hingga tingkat nasional. Usaha kursi karet pak Ganden juga pernah diwawancarai oleh beberapa stasiun televisi lokal dan nasional. Dalam acara "Tau Gak Sih" dan "Selamat Pagi” Trans7. Selain itu juga stasiun televisi lokal RCTV dan Radar Cirebon. Pada saat itu juga, usaha kursi karet sangat diminati dan dicari banyak masyarakat.

Sejak adanya pandemi virus corona, usaha kursi karet hampir berhenti. Hanya sebagian yang meminta barang untuk dikirim, ada pula yang meminta barang dengan pembayaran setengah harga, setengah lagi akan dibayar jika kursi terjual semua. Virus corona sangat berpengaruh bagi pengusaha kursi karet, sebelum pandemi pengiriman sebulan bisa tiga sampai lima kali pengiriman. Satu kali kirim sebanyak 30 setel kursi atau satu truk besar, dan semenjak pandemi, sebulan hanya satu kali pengiriman bahkan tidak sama sekali melakukan pengiriman.
Hasil dari dialog bersama kelompok pengrajin UMKM limbah ban menghasilkan banyak informasi terkait proses pembuatan produk dari saat masih menjadi bahan mentah sampai pada proses siap untuk diperjualbelikan. Selain itu, melalui proses wawancara dan observasi juga dapat diketahui beberapa permasalahan terkait dengan pengembangan usaha utamanya di era pandemi Covid-19 saat ini.

Tahapan kegiatan pendampingan selanjutnya adalah dengan melakukan riset atas hasil pendekatan yang telah dilakukan sebelumnya. Yaitu tim pengabdi memberikan usulan program kepada masyarakat untuk dapat meminimalisir permasalahanpermasalahan yang dapat menghambat pemasaran dan eksistensi UMKM limbah ban bekas di masa pandemi Covid-19 seperti sekarang ini. Permasalahan tersebut dapat diminimalisir dengan menciptakan seni kreativitas para pengrajin yang selama ini masih kurang mendapat perhatian. Padahal didalam (Chumairo \& Utami, 2019) dijelaskan bahwa seni kreatifitas mampu mempengaruhi eksistensi suatu industri dan sangat potensial untuk meningkatkan nilai jual suatu produk. 
Setelah dilakukan diskusi bersama kelompok para pengrajin UMKM limbah ban, maka didapatkan kesepakatan rencana program, pelaksanaan, monitoring melalui sarasehan (musyawarah) untuk didapatkan kesepakatan bersama mencapai tujuan pengembangan pemasaran produk olahan limbah ban sehingga bukan musyawarah tersebut bukan hanya menjadi kepentingan ekonomi kelompok usaha saja namun juga sebagai bentuk partisipasi, dukungan dan solidaritas antar para pengrajin UMKM limbah ban yang berpotensi menjadi ekonomi yang berkelanjutan.

Tahapan pemberdayaan selanjutnya sesuai metode PAR yaitu mengimplementasikan hasil pendekatan dan riset secara tepat. Dalam hal ini, masyarakat kelompok usaha diberikan pengetahuan bagaimana menyiasati model marketing di masa pandemi dengan menggunakan teknologi informasi. Penggunaan sosial media bukan saja akan mampu mengenalkan produk secara luas, namun memberikan peluang pembeli lebih besar.

Beberapa langkah yang dijalankan menuju pemberdayaan masyarakat terutama dalam manajemen pemasaran adalah ; (1). Menyiapkan produk yang akan ditampilkan pada media sosial (2). Menentukan target dan jenis media sosial yang akan digunakan sebagai sarana pemasaran (3). Membuat beberapa sarana aplikasi media sosial (4). Menentukan strategi konten dan promosi yang akan diposting (5). Memilih beberapa produk yang sudah disiapkan dengan sarana media sosial yang tersedia (6). Posting produk (7). Membuat jadwal rutin untuk sosial media (8). Menjalin komunikasi yang aktif dan efektif.

Selain itu, tim pengabdian juga membantu kelompok UMKM limbah ban dengan cara memberikan label atau stiker pada setiap produk kursi karet sebagai identitas atas setiap produknya sebagai tanda bahwa kursi tersebut milik pak Ganden. Karena di desa Kasugengan Lor ada beberapa yang memproduksi kursi karet. Dengan adanya pemberian stiker pada kursi karet milik pak Ganden, menjadi ciri khas tersendiri. Disebutkan dalam (Nugrahani, 2015) bahwa label merupakan salah satu prioritas yang perlu dipertimbangkan untuk meningkatkan nilai jual produk.

Selain itu bentuk promosi dilakukan melalui media sosial seperti youtube, instagram, facebook, dan whatsApp. Promosi melalui media sosial ini bertujuan agar kursi karet milik pak Ganden tetap berjalan dengan lancar dan makin banyak peminatnya, berikut contoh strategi pemasaran yang kami lakukan. 


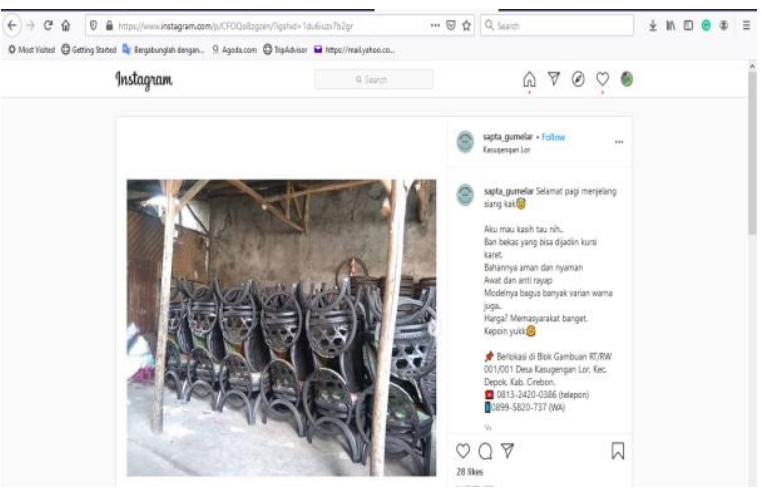

Sumber: Dokumentasi penulis, 2020

Gambar 2. Contoh Strategi Pemasaran Produk pada Instagram

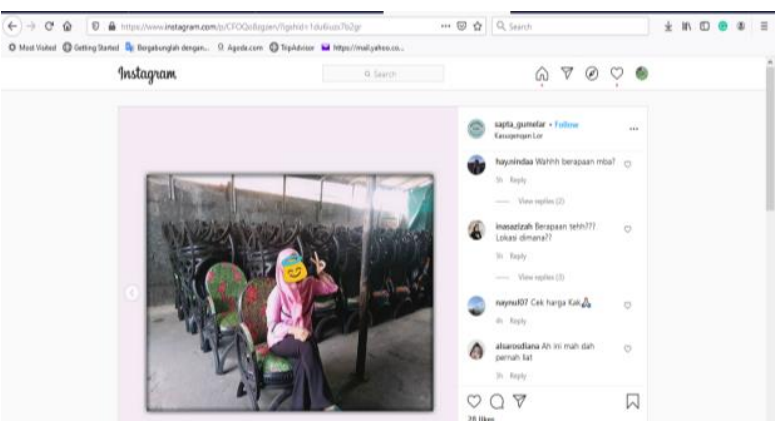

Sumber: Dokumentasi penulis, 2020

Gambar 3. Contoh Strategi Pemasaran Produk pada Instagram

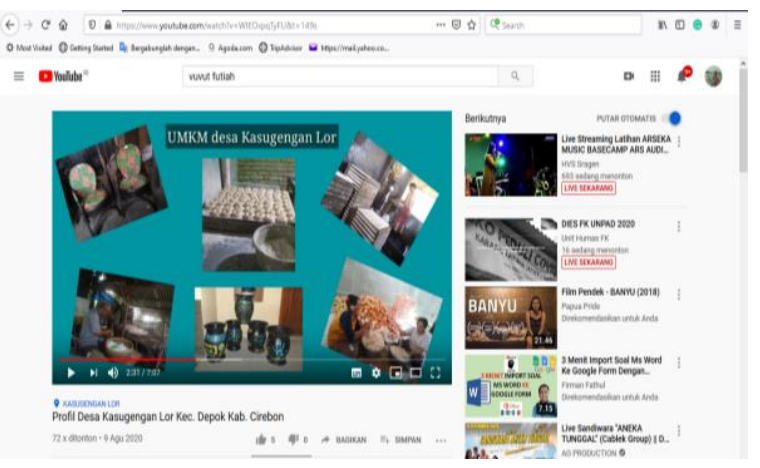

Sumber: Dokumentasi penulis, 2020

Gambar 4. Contoh Strategi Pemasaran Produk pada Youtube p-ISSN 2655-9072 | e-ISSN 2686-1380

Urgensi penggunaan media sosial (marketing digital) sebagai salah satu strategi pemasaran yang tepat melalui pemanfaatan teknologi digital sudah banyak dibahas pada beberapa literatur terdahulu. Beberapa diantaranya antara lain; (Bakhri, 2020) yang mengungkapkan bahwa strategi pemasaran online dinilai mampu memasarkan produk secara lebih tepat sasaran, lebih efektif dan efisien karena bentuk komunikasinya yang intens dan relatif lebih cepat baik dalam mengetahui tanggapan konsumen ataupun dalam hal menyebarluaskan informasi secara tepat kepada konsumen. Persepsi tersebut akhirnya berkaitan dengan hasil penelitian pada beberapa penelitian terdahulu yang sebagian besar mengungkapkan manfaat dan peluang penggunaan teknologi digital dalam pemasaran UMKM. Seperti halnya (Setiawati, 2017) yang membuktikan bahwa strategi pemasaran online berpengaruh positif terhadap laba Usaha Mikro, Kecil dan Menengah (UMKM).

Adapula yang menyebutkan bahwa konsep e-UMKM merupakan strategi atau terobosan baru untuk menembus pasar bebas ASEAN sehingga produk-produk UMKM di Indonesia dapat secara aktif terlibat memasarkan produknya bukan hanya di dalam negeri tetapi juga dilakukan ke luar negeri (Amelia, Prasetyo, \& Maharani, 2017). Selain itu, dengan pemanfaatan media sosial, 
pelaku UMKM dapat memperoleh keuntungan yang lebih, mereka juga dapat melakukan komunikasi secara intens dengan pelanggan karena sebagian masyarakat yang kini cenderung lebih banyak menghabiskan waktunya dengan menggeluti media sosial, (Anugrah, 2020), sehingga pelaku UMKM dapat berpeluang memenuhi capaian target pemasaran produk mereka sekaligus dapat menyelamatkan atau bahkan meningkatkan kondisi ekonomi masyarakat di tengah pandemi Covid-19.

\section{KESIMPULAN}

Kegiatan pengabdian ini berjalan sebagaimana ketentuan metode PAR (Participation Action Research) yang sudah direncanakan. Para pengrajin UMKM limbah ban bekas semangat untuk menjalankan usulan strategi yang kami ajukan dan bantu realisasikan. Beberapa strategi tersebut diantaranya, membuat label produk sebagai identitas dan ciri khas produk demi meningkatkan nilai jual produk. Mereka juga merasa sangat terbantu dengan adanya kegiatan pendampingan ini utamanya terkait pemasaran produk yang dilakukan melalui pemanfaatan teknologi digital (marketing digital) berupa media sosial baik itu Instagram, Youtube, dan Facebook sehingga distribusi produk dalam pasar domestik dapat terselamatkan di masa pandemi Covid-19.

\section{REFERENSI}

Amelia, M. N., Prasetyo, Y. E., \& Maharani, I. (2017). E-UMKM: Aplikasi Pemasaran Produk UMKM Berbasis Android Sebagai Strategi Meningkatkan Perekonomian Indonesia. Jurnal Prosiding Snatif, 1116. Retrieved from https://jurnal.umk.ac.id/index.php/SN A/article/view/1238

Amri, A. (2020). Dampak Covid-19 Terhadap UMKM di Indonesia. Jurnal Brand, 2(1), 147-153. Retrieved from https://www.academia.edu/42672824/

Dampak_Covid-

19_Terhadap_UMKM_di_Indonesia Anugrah, R. J. (2020). Efektifitas Penerapan Strategi Online Marketing Oleh UMKM Dalam Masa Pembatasan Sosial Berskala Besar (PSBB) Corona Viruses Disease 2019 (Covid-19). Jurnal MANOVA, 2(2), 55-65.

Bakhri, S. (2020). Membangun Ekonomi Masyarakat Melalui Pengembangan IKM (Industri Kecil dan Menengah). Yogyakarta: K-Media.

Chumairo, \& Utami, W. S. (2019). Kajian

Eksistensi Industri Kecil Meja dan Kursi Karet Terhadap Kondisi Sosial EKonomi Pengrajin Di Desa Kedungbondo Kecamatan Balen Kabupaten Bojonegoro. Swara Bhumi, 
1(3)

Retrieved

from

Nugrahani, R. (2015). Peran desain grafis

https://jurnalmahasiswa.unesa.ac.id/ind

ex.php/swara-

bhumi/article/view/30234/

Hardilawati, W. laura. (2020). Strategi

Bertahan UMKM di Tengah Pandemi

Covid-19. Jurnal Akuntansi Dan

Ekonomika, 10(1), 89-98.

https://doi.org/10.37859/jae.v10i1.193

4

Hendrawan, A. (2019). Pengaruh Marketing

Digital terhadap Kinerja Penjualan

Produk UMKM Asti Gauri di

Kecamatan Bantasari Cilacap. Jurnal

Administrasi Dan Kesekretarisan, 4(1),

2019. Retrieved from http://jurnal.stiks-

tarakanita.ac.id/index.php/JAK/article/ view/189

Mahmudah, N., Chasanatin, H., Alkautsar, M.

S., \& Paripurna, M. W. (2020).

Pengolahan Durian dalam

Pemberdayaan Ekonomi Masyarakat

Desa Tanjung Agung Pesawaran.

DEDIKASI: Jurnal Pengabdian

Masyarakat, 2(1), 76-91.

pada label dan kemasan produk makanan umkm. Jurnal Imajinasi, $I X(2)$, 127-136. Retrieved from https://journal.unnes.ac.id/nju/index.ph p/imajinasi/article/view/8846

Setiawati, I. (2017). Pengaruh Strategi Pemasaran Online Terhadap Peningkatan Laba UMKM. Strategi Komunikasi Pemasaran, 1(1), 343-347. Retrieved from file:///C:/Users/BAYU/Downloads/Do cuments/263-760-1-PB.pdf

Soedarwo, V. S. D., Zuriah, N., Yuliati, R., \& Suwignyo. (2017). Pemberdayaan masyarakat melalui pendidikan nonformal berbasis potensi lokal dalam membangun desa wisata adat. Jurnal Sosiologi Pendidikan Humanis, 2(2), 96-102.

Sugiri, D. (2020). Menyelamatkan Usaha Mikro, Kecil dan Menengah dari Dampak Pandemi Covid-19. Fokus Bisnis : Media Pengkajian Manajemen Dan Akuntansi, 19(1), 76-86. https://doi.org/10.32639/fokusbisnis.v1 9i1.575 